\section{Uma Escola de Saúde Pública para os Anos 90}

Jaime A. Oliveira *

Momentos como esse, de passagem de década e, além do mais, de mudança de governo, costumam estimular, em diferentes áreas, a reflexão sobre o que vem ocorrendo nos últimos tempos e sobre o que se espera do futuro imediato.

No que tange à Escola Nacional de Saúde Pública, reproduzimos, à guisa de editorial para este último número dos seus "Cadernos" em 1989, uma passagem com este caráter do Programa de Trabalho da Diretoria recém-eleita.

"Fundada em 1954, a ENSP, teve, no entanto, funcionamen to precário até sua instalação na atual sede (adaptada para tal fim), em 1966.

Mas, logo a seguir, seria, também ela, afetada pelo período de caça às bruxas em Manguinhos, a partir do final da década. O que fez com que os anos seguintes fossem anos difíceis, em que a sobrevivência da Escola dependeu do esforço e dedicação de uns poucos e bravos companheiros.

Semi-sucateada pelo descaso com a Saúde Pública que marcou os anos mais duros do regime militar, somente em meados dos anos 70 - num contexto econômico e político que começava a modificar-se - é que a Escola voltou a receber uma injeção minimamente significativa de recursos humanos e financeiros.

Respondeu à altura, tomando-se, em fins dos anos $70 /$ início dos anos 80 , um dos principais pólos de reflexão crítica sobre os desmandos viabilizados pela ditadura no âmbito da nossa Política de Saúde.

Mas a produção gerada naquele período pela ENSP e por instituições similares era marcada pela posição relativamente cômoda de quem não tinha, e nem sequer vislumbrava, à época, qualquer possibilidade de acesso, e muito menos de influência, sobre as instituições-chave do setor.

Cadernos de Saúde Pública, RJ, 5 (4): 361-364, out/dez, 1989.
* Vice-Diretor da Escola Nacional de Saúde Pública. 
Ao longo dos anos 80, no entanto, o desenvolvimento - apesar de seus conhecidos percalços, restriçōes, e caráter conservador - do processo de transição política no país tem viabilizado, mal ou bem, $o$ fato de que, através de diferentes vias institucionais e partidárias, amplia-se progressivamente a articulação entre a Escola, seus profissionais e seus egressos e o sistema de atenção à saúde, em diferentes níveis, instâncias e setores. Bem como tem viabilizado também (embora, aqui, ainda de forma incipiente) o início de um processo de articulação com diferentes setores da sociedade civil crescentemente mobilizados em torno ao tema da saúde.

A conseqüência é a de que, hoje, ampliaram-se muitíssimo, por comparação ao passado recente, não só as responsabilidades, mas também a diversidade, a heterogeneidade e a complexidade dos temas a serem abordados pela Escola. Fenômeno exacerbado, ainda, pela amplitude que se pretende emprestar - desde a 8: CNS, a nova Constituição e a LOS - à noção de saúde enquanto direito de cidadania e obrigação do Estado.

Esta evoluçāo recente dos acontecimentos tem sido expressão na estrutura da Escola. Os últimos anos - correspondentes à última gestão - têm sido marcados por uma forte expansão quantitativa dos quadros técnicos e administrativos; e das atividades institucionais no âmbito do Ensino, da Pesquisa, da Prestação de Serviços e da Cooperação Técnica.

Proliferam, em conseqüencia, os Núcleos, Centros, Projetos e Cursos; novas formas de organização, paralelas à expansão das anteriormente existentes. E, obviamente, começam a surgir e manifestar-se, a partir daí, de forma mais intensa, os gargalos, nós, e bloqueios burocrático-administrativos, tão intensamente vividos por todos nós hoje.

Este rápido retrospecto da evolução da Escola nos últimos anos nos permite, finalmente, apontar para os grandes problemas que devem informar um seu projeto institucional, e que são, em síntese, a nosso ver, os seguintes:

1:) Como dar continuidade e desenvolvimento ao necessário processo de capacitação técnica positiva, 
propositiva - de formulaçāo de altemativas concretas de engenharia técnica e política - da Escola, frente aos complexíssimos e heterogêneos problemas postos hoje pela gestão de um sistema de saúde gigantesco, extremamente problemático e em processo de transformação.

Em outras palavras: como ir além - não negando-a, mas sim superando-a - da tradição mais marcada e restritivamente negativa, reflexiva e crítica, que, como foi dito acima, caracterizou centralmente um dado período da vida da instituição.

2:) Como, apesar do que acabamos de assinalar, preservar, com todas as forças, a inegociável autonomia acadêmica da instituição, enquanto condição sine qua do seu amadurecimento intelectual. Autonomia que deve expressar-se tanto na liberdade de crítica e de opinião frente a qualquer tema, instância ou corrente de opinião, quanto na não-restrição dos objetos da in vestigação e docência a qualquer tipo de exigência pragmática, de resultados imediatistas, de curto prazo.

Em suma: como conciliar o aprimoramento da capacitação técnica na resposta aos complexos problemas de natureza administrativa e gerencial do sistema de saúde, com a preservação e desenvolvimento da tradiçăo totalizante, reflexiva e crítica, que é um traço importante da nossa experiência institucional.

3:) Identificar e apontar soluções para os principais problemas de natureza administrativa, política e financeira à constituição de uma instituiçāo com o tipo de perfil delineado acima.

Problemas que se situam: na estrutura da Escola, tal como definida pelo seu recém-elaborado Regimento; na sua infra-estrutura administrativa e físi- . ca; nas suas relações com a FIOCRUZ; com as demais instituições do setor saúde e da sociedade civil organizada; com as instituiçōes financiadoras governamentais e privadas; e nas diretrizes de política governamental para pessoal e salários." 
Estes são, a nosso ver, os desafios centrais que se colocam para a Escola Nacional de Saúde Pública neste limiar de década, de modo a que ela possa ter uma relação de superação não-mecânica com seu próprio passado e contribuir para o enfrentamento das exigências técnicas, intelectuais e políticas postas pelo campo da Saúde Coletiva, para o futuro imediato. 